\title{
Values of Selected Haematological Indicators in Six Species of Feathered Game
}

\author{
Eva Straková, Pavel Suchý, Romana Kábelová, František Vitula, Ivan Herzig \\ Department of Nutrition, Animal Husbandry and Animal Hygiene, Faculty of Veterinary Hygiene and Ecology, \\ University of Veterinary and Pharmaceutical Sciences, Brno, Czech Republic \\ Received November 9, 2009 \\ Accepted June 15, 2010
}

\begin{abstract}
The present paper extends the knowledge of selected blood indicators in six species of feathered game such as helmeted guineafowl (Numida meleagris), common pheasant (Phasianus colchicus), Japanese quail (Coturnix coturnix japonica), chukar (Alectoris chucar), grey partridge (Perdix perdix) and wild turkey (Meleagris gallopavo), reared in the Czech Republic and Europe. The red blood cell (RBC) values in individual species of feathered game ranged as follows: the mean RBC counts varied in a range of $2.10-2.58 \mathrm{~T} / 1$; haematocrit values were in a range of $0.33-0.391 / 1$; haemoglobin concentration varied in a range of $101.20-129.13$ $\mathrm{g} / \mathrm{l}$; mean corpuscular haemoglobin concentration (MCHC) ranged from 28.63 to $35.44 \%$; mean corpuscular haemoglobin $(\mathrm{MCH})$ varied in a range of $46.15-62.07 \mathrm{pg}$ and the mean corpuscular volume (MCV) was 147.66 - $178.20 \mathrm{fl}$. Except for the total concentration of haemoglobin and the mean corpuscular haemoglobin concentration, no significant differences were found between the mean values of RBC values in individual species of feathered game. However, some differences between species were found in white blood cell (WBC) values, ranging as follows: the total WBC count ranged from 13.55 to $26.90 \mathrm{G} / 1$, basophil granulocytes from 0.011 to $0.110 \mathrm{G} / 1$, eosinophil granulocytes from 0.011 to $0.593 \mathrm{G} / 1$, neutrophil granulocytes from 1.868 to 6.661 $\mathrm{G} / 1$, lymphocytes from 10.937 to $20.922 \mathrm{G} / 1$ and monocytes from 0.034 to $0.199 \mathrm{G} / 1$. Most values showed significant $(P \leq 0.05)$ to highly significant $(P \leq 0.01)$ interspecies differences.

The main goal of the study was to investigate selected haematological indicators in six major species of feathered game.
\end{abstract}

Blood count, helmeted guineafowl, common pheasant, Japanese quail, chukar, grey partridge, wild turkey

Only a few exact experiments on the haematological profiles in feathered game reared in European conditions have been reported in literature. Haematological tests were usually performed in domesticated birds and served as supplementary data obtained during various experimental procedures. Partial haematological studies in gallinaceous birds (the order Galliformes), namely in hens, were reported by Jeřábek et al. (1993), Itoh et al. (1995), Uko and Ataja (1996), Puvadolpirod and Thaxton (2000), Straková et al. (2001), Lichovníková et al. (2002), Suchý et al. (2004), and Tůmová et al. (2004). Interesting haematological studies conducted with breeding roosters were also published by Král and Suchý (2000). Haematological indicators in broiler chickens were investigated by Maxwell et al. (1990; 1992) and Straková et al. (1993) who studied the effect of a diet on these indicators, and by Bedáňová et al. (2003) who focused on the effect of acute and chronic thermal stress. However, there is still a lack of data on the haematological profile in other species of poultry. Changes in the haematological profile in breeding turkey during sexual maturation were only studied by Straková et al. (1996), whereas Suchý et al. (1995) and Bounous (2000) focused on the haematological indicators in the turkey during the fattening period, and Straková et al. (1994) and Mihailov et al. (1999) investigated the Japanese quail. The knowledge of haematological values in individual species of feathered game is still far from being complete. Some RBC and WBC counts were documented by Prinzinger and Misovic (1994). The results of haematological tests in pheasants were reported by Torgowski and Kontecka (1998) and Hauptmanová et al. (2006).

Address for correspondence:

Prof. Ing. Eva Straková, Ph.D.

Department of Nutrition, Animal Husbandry and Animal Hygiene

Faculty of Veterinary Hygiene and Ecology

University of Veterinary and Pharmaceutical Sciences Brno

Palackého 1-3, 61242 Brno, Czech Republic

Phone: +420541562672

Fax: +420 541562675

E-mail: strakovae@ vfu.cz

http://www.vfu.cz/acta-vet/actavet.htm 
The present paper attempts to broaden the current knowledge about the individual indicators of the haematological profile in six major species of feathered game reared in the Czech Republic and throughout Europe. It also explores the potential inter-species differences and compares them with the domesticated species. The main goal of this haematological testing was to investigate the haematological profile in six species of feathered game, and evaluate the differences between individual species.

\section{Materials and Methods}

Animals and procedures

The haematological profile was monitored in six species of feathered game: helmeted guineafowl (Numida meleagris), common pheasant (Phasianus colchicus), Japanese quail (Coturnix coturnix japonica), chukar (Alectoris chucar), grey partridge (Perdix perdix) and wild turkey (Meleagris gallopavo). Birds were reared in the accredited animal enclosure (aviaries) intended for the rearing of feathered game owned by the University of Veterinary and Pharmaceutical Sciences Brno, in controlled conditions, using the same method of treatment and the same nutrition content. The birds were fed a complete feeding mixture intended for laying pheasant hens (produced by ADW Agro, a.s. Krahulov). $1 \mathrm{~kg}$ of the feeding mixture contained the following ingredients: 135 $\mathrm{g}$ of water, $145 \mathrm{~g}$ crude protein $(\mathrm{N} \times 6.25), 39 \mathrm{~g}$ of fat, $27 \mathrm{~g}$ of fibre, $98 \mathrm{~g}$ of ash, $3.4 \mathrm{~g}$ of methionine, $15.5 \mathrm{mg}$ of copper, $65.0 \mathrm{mg}$ of vitamin E (alpha-tocopherol), $15276 \mathrm{IU}$ of vitamin A, $3000 \mathrm{IU}$ of vitamin D3, 5500.41 EXU of endo-1,4- $\beta$-xylanase, $9.0 \mathrm{mg}$ of butylhydroxytoluene (BHT), and $1.20 \mathrm{mg}$ of butylhydroxyanisole (BHA).

\section{Haematological testing}

In February, single blood samples were collected from sexually mature birds (10 months of age) intended for reproduction that were hatched and reared in the previous year. Ten clinically healthy individuals $(5 \circ$ and 5 ) from each species were subjected to the puncture of vena basilica to take blood samples which were then placed in heparinized test tubes. Haematological tests were performed using conventional methods (Doubek et al. 2003). Red and white blood cell counts (RBC, WBC) were determined using a flask method (dilution and counting blood cells using a Bürker chamber); the haemoglobin concentration $(\mathrm{Hb})$ was determined photometrically using the Drabkin solution at a wavelength of $540 \mathrm{~nm}$. The haematocrit value (PCV) was determined using the capillary microhaematocrit method according to Janetzki (Doubek et al. 2003). The values found were used to calculate the mean corpuscular haemoglobin concentration $[\mathrm{MCHC}=\mathrm{Hb}:(\mathrm{PCVHk} \cdot 10)]$, the mean corpuscular haemoglobin $(\mathrm{MCH}=\mathrm{Hb}: \mathrm{Er})$, and the mean corpuscular volume $[\mathrm{MCV}=(\mathrm{Hk} \cdot 1000): \mathrm{Er}]$. Following blood collection, the blood smear was prepared to determine the differential count; after panoptic staining, the number of individual species of leukocytes such as basophil granulocytes $(\mathrm{Ba})$, eosinophil granulocytes (Eo), neutrophil granulocytes (Ne), lymphocytes (Ly) and monocytes (Mo) was determined.

\section{Statistical evaluation}

The results obtained were processed using mathematical and statistical methods in Unistat 5.6 (2005); the average values and their differences were evaluated by means of multiple comparison using Tukey-HSD test, at a level of significance of $P \leq 0.01$ and $P \leq 0.05$. Each value is presented by the mean (x) and by the standard deviation $( \pm \mathrm{SD})$.

\section{Results and Discussion}

The examination of red blood cells (Table 1) shows that the mean values of RBC count in six species of feathered game range from $2.10 \pm 0.370 \mathrm{~T} / 1$ (wild turkey) to $2.58 \pm 0.505$ $\mathrm{T} / 1$ (common pheasant). No significant differences between species were found in the mean values of the RBC. Our findings are in a complete agreement with those reported by Jeřábek et al. (1993) in hens (2.24 \pm 0.357 T/1), Král and Suchý (2000) in breeding roosters, Straková et al. $(1993 ; 1996 ; 2001)$ in broilers $(2.51 \pm 0.390 \mathrm{~T} / 1)$, breeding turkey $(2.41 \mathrm{~T} / 1)$, and laying hens $(2.52 \pm 0.501 \mathrm{~T} / 1)$, by Suchý et al. (2004) in meat-type hens $(1.95 \pm 0.490 \mathrm{~T} / \mathrm{l})$ and layers $(2.36 \pm 0.389 \mathrm{~T} / \mathrm{l})$ but slightly lower as compared to the results reported by Hauptmanová et al. (2006) in pheasants $(3.58 \pm 0.780 \mathrm{~T} / \mathrm{l})$.

Non-significant differences were also found in the mean haematocrit values (PCV) that ranged from $0.33 \pm 0.031 / 1$ in wild turkey to $0.39 \pm 0.0981 / 1$ or $0.39 \pm 0.0641 / 1$ in Japanese quail and grey partridge, respectively. The scatter of values corresponds to the finding reported by Hauptmanová et al. (2006) in common pheasant. The non-significance of differences between the mean values of the above-mentioned indicators is caused by the relatively low variability in average values.

Significant differences were found in the mean values of haemoglobin concentration, 
Table 1. Mean values of RBC count $(x \pm \mathrm{SD})$ in the monitored species of feathered game

\begin{tabular}{|l|r|r|r|r|r|c|}
\hline Species of feathered game & RBC T/1 & PCV 1/1 & Hb g/l & MCHC \% & MCH pg & MCV fl \\
\hline Helmeted guineafowl & 2.150 & 0.360 & $129.130^{\mathrm{A}}$ & 35.440 & $62.070^{\mathrm{a}}$ & 176.730 \\
(Numida meleagris) & \pm 0.451 & \pm 0.038 & \pm 6.350 & \pm 4.281 & \pm 10.792 & \pm 33.081 \\
\hline Common pheasant & 2.580 & 0.370 & 116.080 & 31.270 & $46.150^{\mathrm{b}}$ & 147.660 \\
(Phasianus colchicus) & \pm 0.505 & \pm 0.065 & \pm 13.730 & \pm 3.124 & \pm 8.482 & \pm 23.154 \\
\hline Japanese quail & 2.390 & 0.390 & $125.290^{\mathrm{a}}$ & 34.580 & 53.880 & 165.810 \\
(Coturnix coturnix Japonica) & \pm 0.517 & \pm 0.098 & \pm 25.520 & \pm 16.689 & \pm 13.109 & \pm 34.893 \\
\hline Chukar & 2.570 & 0.380 & 116.070 & 30.400 & $46.220^{\mathrm{b}}$ & 153.190 \\
(Alectoris chucar) & \pm 0.435 & \pm 0.048 & \pm 14.540 & \pm 3.230 & \pm 9.599 & \pm 32.752 \\
\hline Grey partridge & 2.230 & 0.390 & 112.240 & 28.630 & 50.950 & 178.200 \\
(Perdix perdix) & \pm 0.394 & \pm 0.064 & \pm 19.700 & \pm 2.051 & \pm 7.942 & \pm 26.532 \\
\hline Wild turkey & 2.100 & 0.330 & $101.200^{\mathrm{B}, \mathrm{b}}$ & 30.710 & 50.360 & 162.090 \\
(Meleagris gallopavo) & \pm 0.370 & \pm 0.030 & \pm 11.650 & \pm 2.874 & \pm 14.332 & \pm 33.348 \\
\hline
\end{tabular}

${ }^{\mathrm{a}: \mathrm{b}}$ means in the same row followed by different superscript differ $(P \leq 0.05)$

A:B means in the same row followed by different superscript differ $(P \leq 0.01)$

The total number of red blood cells - RBC; hematocrit value - PCV; haemoglobin - Hb; the mean corpuscular haemoglobin concentration - MCHC; mean corpuscular haemoglobin - $\mathrm{MCH}$; mean corpuscular volume - MCV

ranging between $101.20 \pm 11.650 \mathrm{~g} / \mathrm{l}$ (wild turkey) and $129.13 \pm 6.350 \mathrm{~g} / \mathrm{l}$ (helmeted guineafowl) that was the highest value found. A highly significant difference $(P \leq 0.01)$ was found between the mean $\mathrm{Hb}$ value in helmeted guineafowl $(129.13 \mathrm{~g} / \mathrm{l})$ and that in wild turkey (101.20 g/l). Similarly, the mean Hb value in Japanese quail (125.29 g/l) differed significantly $(P \leq 0.05)$ from that in wild turkey $(101.20 \mathrm{~g} / \mathrm{l})$. The values are comparable with those reported by Hauptmanová et al. (2006) in common pheasant (115.00 \pm $20.500 \mathrm{~g} / \mathrm{l})$. Significantly lower values of $\mathrm{Hb}$ were reported by Jeřábek et al. (1993) in layers (76.08 $\pm 5.710 \mathrm{~g} / \mathrm{l})$, by Straková et al. in broilers (1993) and layers (2001) and also by Suchý et al. (2004).

No significant difference was found between the monitored species of feathered game in the MCHC values, as the mean values ranged between $28.63 \pm 2.05 \%$ (grey partridge) and $35.44 \pm 4.280 \%$ (helmeted guineafowl). Similar values have also been reported in literature (Straková et al. 1993; Hauptmanová et al. 2006). The MCV values ranged from 147.66 $\pm 23.150 \mathrm{fl}$ (common pheasant) to $178.20 \pm 26.532 \mathrm{fl}$ (grey partridge). Such values are higher as compared to those reported by Straková et al. (1993) and Hauptmanová et al. (2006). A significant difference $(P \leq 0.05)$ was found in the $\mathrm{MCH}$ value, between the highest mean value $(62.07 \pm 10.792 \mathrm{pg}$ in helmeted guinea fowl $)$ and the values of $46.15 \pm$ $8.48 \mathrm{pg}$ in common pheasant and $46.22 \pm 9.599 \mathrm{pg}$ in chukar. Such values are also higher than those reported in literature (Straková et al. 1993; Hauptmanová et al. 2006).

Unlike RBC values, the results of white blood cell values showed a trend toward increased interspecies variability (Table 2). The total leukocyte count (Le) in individual species of feathered game varied in a range from $13.55 \pm 4.591 \mathrm{G} / 1$ (common pheasant) to $26.90 \pm$ $6.433 \mathrm{G} / 1$ (wild turkey). The highest mean concentration of Le (26.90 G/1 in wild turkey) differed highly significantly $(P \leq 0.01)$ from the mean concentration in common pheasant $(13.55 \mathrm{G} / 1)$, helmeted guineafowl $(14.35 \mathrm{G} / \mathrm{l})$, and grey partridge $(17.45 \mathrm{G} / \mathrm{l})$. The second highest mean count of Le $(24.00 \pm 5.720 \mathrm{G} / 1$ in chukar) also differed highly significantly $(P \leq 0.01)$ from those found in common pheasant and helmeted guineafowl. The high Le count in wild turkey was affected highly significantly $(P \leq 0.01)$ by the increased mean concentration of lymphocytes (Ly) compared to the findings in other monitored species $(10.937 \mathrm{G} / 1$ in common pheasant; $11.598 \mathrm{G} / 1$ in helmeted guineafowl; $12.176 \mathrm{G} / 1$ in grey partridge a $13.010 \mathrm{G} / 1$ in Japanese quail). This relation between Le and individual types of leukocytes was not observed in other species of feathered game. Similar ranges of 
Table 2. The mean values of the WBC count $(\mathrm{x} \pm \mathrm{SD})$ in the monitored species of feathered game

\begin{tabular}{|c|c|c|c|c|c|c|}
\hline Species of feathered game & Le $\mathrm{G} / 1$ & $\mathrm{Ba} \mathrm{G} / 1$ & Eo G/1 & $\mathrm{Ne} \mathrm{G/1}$ & Ly G/1 & Mo G/1 \\
\hline Helmeted guineafowl & $14.350^{\mathrm{B}}$ & $0.011^{b}$ & $0.045^{\mathrm{B}, \mathrm{b}}$ & $2.583^{\mathrm{a}}$ & $11.598^{\mathrm{B}}$ & 0.105 \\
\hline (Numida meleagris) & \pm 3.163 & \pm 0.023 & \pm 0.060 & \pm 1.060 & \pm 2.777 & \pm 0.100 \\
\hline Common pheasant & $13.550^{\mathrm{B}}$ & 0.022 & $0.593^{\mathrm{A}}$ & $1.868^{\mathrm{A}, \mathrm{a}}$ & $10.937^{\mathrm{B}, \mathrm{b}}$ & 0.074 \\
\hline (Phasianus colchicus) & \pm 4.591 & \pm 0.038 & \pm 0.348 & \pm 1.315 & \pm 3.798 & \pm 0.147 \\
\hline Japanese quail & 20.100 & $0.110^{\mathrm{a}}$ & 0.270 & $6.661^{\mathrm{Bb}}$ & $13.010^{\mathrm{B}}$ & $0.038^{\mathrm{b}}$ \\
\hline (Coturnix coturnix Japonica) & \pm 8.653 & \pm 0.146 & \pm 0.377 & \pm 3.614 & \pm 6.286 & \pm 0.065 \\
\hline Chukar & $24.000^{\mathrm{A}}$ & 0.059 & $0.398^{\mathrm{a}}$ & $5.424^{b}$ & $17.671^{\mathrm{a}}$ & 0.099 \\
\hline (Alectoris chucar) & \pm 5.720 & \pm 0.057 & \pm 0.323 & \pm 2.581 & \pm 5.176 & \pm 0.059 \\
\hline Grey partridge & $17.450^{\mathrm{B}}$ & 0.018 & $0.082^{\mathrm{B}}$ & $4.660^{\mathrm{b}}$ & $12.176^{\mathrm{B}}$ & $0.199^{\mathrm{a}}$ \\
\hline (Perdix perdix) & \pm 4.687 & \pm 0.039 & \pm 0.098 & \pm 3.119 & \pm 2.645 & \pm 0.199 \\
\hline Wild turkey & $26.900^{\mathrm{A}}$ & $0.011^{\mathrm{b}}$ & $0.011^{\mathrm{B}}$ & 5.923 & $20.922^{\mathrm{A}}$ & $0.034^{\mathrm{b}}$ \\
\hline (Meleagris gallopavo) & \pm 6.433 & \pm 0.034 & \pm 0.034 & \pm 3.165 & \pm 6.152 & \pm 0.071 \\
\hline
\end{tabular}

a:b means in the same row followed by different superscript differ $(P \leq 0.05)$

A:B means in the same row followed by different superscript differ $(P \leq 0.01)$

Le - leucocytes; Ba - basophils; Eo - eosinophils; Ne - neutrophils; Ly - lymphocytes; Mo - monocytes

Le concentration were reported by Král and Suchý (2000), Suchý et al. (2004) and Hauptmanová et al. (2006). Great variability in the Le count was reported by numerous authors (Campbell 1994; Hauptmanová et al. 2006) as being affected by a variety of factors such as season, individual properties, stress, immune state, and the collection of blood (Maxwell and Robertson 1998).

The highest mean concentrations of individual morphological types of leukocytes were found in basophils $(\mathrm{Ba})(0.110 \mathrm{G} / 1$ in Japanese quail), eosinophils $(0.593 \mathrm{G} / 1$ in common pheasant), neutrophils (6.661 G/1 in Japanese quail) and monocytes $(0.199 \mathrm{G} / 1$ in grey partridge). Significant differences between individual types of white cells are illustrated in Table 2. Due to very high variability in individual types of leukocytes (Ba, Eo, Ne, Mo), the differences between the mean values cannot be considered as the differences between species.

The values of white blood cell count in six monitored species of feathered game can be compared with the findings reported by Hauptmanová et al. (2006) in common pheasant and Straková et al. (1994) in Japanese quail. Other reported ranges were obtained in domesticated species of poultry (Suchý et al. 1995; Straková et al. 1996). These authors published the ranges of values for individual indicators which would also cover the majority of the results of haematological studies mentioned in this paper.

Generally, the haematological profile in birds is affected by a variety of factors such as the diet, environment, production and reproduction, etc. It is not therefore feasible to obtain the values that could be considered as reference values. Since the knowledge of haematological values in individual species of feathered game is rather incomplete, the values presented in this paper may serve as a guide to asses the state of health in the monitored birds.

\section{Hodnoty vybraných hematologických ukazatelů u šesti druhů pernaté zvěře}

Předložená práce doplňuje stávající znalosti o vybraných hematologických ukazatelích u šesti druhů pernaté zvěře, chované v našich a evropských podmínkách: perličky obecné (Numida meleagris), bažanta obecného (Phasianus colchicus), křepelky japonské (Coturnix coturnix japonica), orebice čukar (Alectoris chucar), koroptve polní (Perdix perdix) a krocana divokého (Meleagris gallopavo). U červené složky krevního obrazu se u jednotlivých druhů pernaté zvěře pohybovaly průměrné hodnoty celkového počtu 
erytrocyti̊ $(\mathrm{RBC})$ v rozmezí 2,10 až $2,58 \mathrm{~T} / 1$, hematokritové hodnoty 0,33 až 0,39 1/1, obsahu hemoglobinu 101,20 až 129,13 g/l, průměrné koncentrace hemoglobinu v erytrocytu 28,63 až $35,44 \%$, průměrného obsahu hemoglobinu v erytrocytu 46,15 až 62,07 pg a průměrného objemu erytrocytu 147,66 až 178,20 fl. Vyjma celkového obsahu hemoglobinu a průměrného obsahu hemoglobinu v erytrocytu, nebyly mezi průměrnými hodnotami sledovaných ukazatelů červené složky krve mezi jednotlivými druhy pernaté zvěře potvrzeny statisticky významné rozdíly. Určitá mezidruhová rozdílnost byla prokázána u ukazatelů bílé složky krevního obrazu. V rámci jednotlivých druhů pernaté zvěře se sledované ukazatele pohybovaly v rozmezí průměrných hodnot u celkového počtu leukocytů 13,55 až $26,90 \mathrm{G} / 1$, bazofilních granulocytů 0,011 až $0,110 \mathrm{G} / 1$, eozinofilních granulocytů 0,011 až $0,593 \mathrm{G} / 1$, neutrofilních granulocytů 1,868 až $6,661 \mathrm{G} / 1$, lymfocytů 10,937 až 20,922 G/1 a monocytů 0,034 až 0,199 G/1. Mezi průměrnými hodnotami většiny ukazatelů, byly potvrzeny průkazné $(P \leq 0.05)$ až vysoce průkazné $(P \leq 0.01)$ mezidruhové rozdíly.

\section{Acknowledgements}

Financial support from the Ministry of Education, Youth, and Sports of the Czech Republic (Grant No MSMT $6215712402)$ is gratefully acknowledged.

\section{References}

Bedáňová I, Voslářová E, Večerek V, Straková E, Suchý P 2003: The haematological profile of broilers under acute and chronic heat stress at $30 \pm 1{ }^{\circ} \mathrm{C}$ level. Folia Vet 47: 188-192

Bounous DI, Wyatt RD, Gibbs PS, Gilburn JV, Quist CF 2000: Normal haematologic and serum biochemical reference for juvenile wild turkeys. J Wildl Dis 36: 393-396

Campbell TW 1994: Hematology. In: Ritchie BW, Harrison GJ, Harrison LR (eds.): Avian Medicine: Principles and Application. Wingers Publishing, Inc., Lake Worth, Florida. 176-198

Doubek J et al. 2003: Veterinární hematologie. 1. vydání, Novico a.s. ISBN 80-86542-02-5. 464 p

Hauptmanová K, Malý M, Literák I 2006: Changes of haematological parameters in common pheasant throughout the year. Vet Med Czech 51: 29-34

Itoh N, Moritsu Y, Ichikawa S 1995: Comparison of blood chemical values of Japanese quail, White Leghorns and broiler chickens. J Vet Med Jpn 48: 97-101

Jeřábek S, Suchý P, Illek J, Straková E, Zelenka J 1993: Haematological and some biochemical parameters of the blood of hens with damaged end integral shells. Živoč Výr 38: 145-151

Král I, Suchý P 2000: Haematological studies in adolescent breeding cocks. Acta Vet Brno 69: 189-194

Lichovníková M, Zeman L, Klecker D, Fialová M 2002: The effect of the long-term administration of dietary lipase on the performance of laying hens. Czech J Anim Sci 47: 141-145

Mihailov R, Lasheva V, Lashev L 1999: Some hematological values in Japanese quails. Bulg J Vet Med 2: 137-139

Maxwell MH, Hocking PM, Robertson GW 1992: Differential leucocyte responses to various degrees food restriction in broilers, turkeys and ducks. Br Poult Sci 33: 177-187

Maxwell MH, Robertson GW 1998: The avian basophil leukocyte: a review. World Poult Sci J 51: 307-325

Maxwell MH, Robertson GW, Spence S, McCorquodale CC 1990: Comparison of haematological values in restricted and ad libitum-fed domestic fowls: White blood cells and thrombocytes. Br Poult Sci 33: 399-405

Prinzinger R, Misovic A 1994: Vogelblut - eine allometrische Übersicht der Bestandteile. J Ornitol 135: 133-165

Puvadolpirod S, Thaxton J 2000: Model of physiological stress in chickens. 2. Dosimetri of adrenocorticotropin. Poult Sci 79: $370-376$

Straková E, Suchý P, Illek J 1996: Variations of hematological indicators in breeding stags in the sexual maturation period. Živoč Výr 41: 199-203

Straková E, Suchý P, Klecker D 1993: Changes in haematological and biochemical characteristics of blood broilers during fattening. Živoč Výr 38: 725-734

Straková E, Suchý P, Klecker D, Illek J 1994: Haematological and biochemical indicators of the blood in Japanese quail during nursing and laying periods. Živoč Výr 39: 409-419

Straková E, Večerek V, Suchý P, Křesala P 2001: Red and white blood-cell analysis in hens during the laying period. Czech J Anim Sci 46: 388-392

Suchý P, Straková E, Jarka B, Thiemel J, Večerek V 2004: Differences between metabolic profiles of egg-type and meat-type hybrid hens. Czech J Anim Sci 49: 323-328

Suchý P, Straková E, Klecker D 1995: Variations in hematological indicators in turkeys during fattening. Vet Med Czech 40: 181-186 
Torgowski J, Kontecka H 1998: Effect of the addition of vitamin C and iron to pheasant (Phasianus colchicus) diets on their production and haematological indices (in Polish). Rocz Akad Rol w Poznaniu, CCCII, Zootechnika 50: $235-242$

Tůmová E, Hartlová H, Ledvinka Z, Fučíková A 2004: The effect of digitonin on egg quality, cholesterol content in eggs, biochemical and haematological parameters in laying hens. Czech J Anim Sci 49: 33-37

Uko O, Ataja A 1996: Haematological studies of pure indigenous domestic fowl (Gallus domesticus) and guinea fowl (Numida meleagris) in north-west Nigeria. Revue Elev Med Vet Pays Trop 49: 257-262 